\title{
Superfluous Falstaff: Morality and Structure
}

\section{Michael Hattaway}

\section{Q OpenEdition \\ Journals}

\section{Electronic version}

URL: http://journals.openedition.org/shakespeare/1033

DOI: 10.4000/shakespeare.1033

ISSN: 2271-6424

\section{Publisher}

Société Française Shakespeare

\section{Printed version}

Date of publication: 1 November 2007

Number of pages: $75-87$

ISBN: 2-9521475-4-X

Electronic reference

Michael Hattaway, «Superfluous Falstaff: Morality and Structure », Actes des congrès de la Société française Shakespeare [Online], 25 | 2007, Online since 10 February 2008, connection on 01 May 2019. URL : http://journals.openedition.org/shakespeare/1033; DOI : 10.4000/shakespeare.1033 


\section{Shakespeare et l'excès}

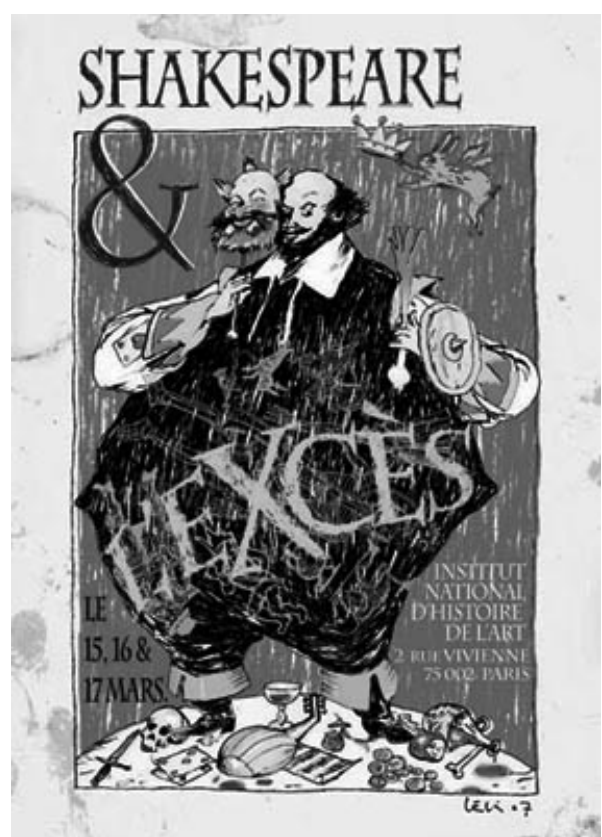

actes du Congrès

organisé par la

SOCIÉTÉ FRANÇAISE SHAKESPEARE

les 15,16 et 17 mars 2007

textes réunis par

Pierre KAPITANIAK

sous la direction de

Jean-Michel DÉPRATS 
COUVERTURE :

Edouard Lekston, Falstaff, 2007

conception graphique et logo

Pierre Kapitaniak

\section{(C) 2007 Société Française Shakespeare \\ Institut du Monde Anglophone}

Université de Paris III - Sorbonne Nouvelle

5 rue de l'École de Médecine 75006 Paris

www.societefrancaiseshakespeare.org

Tous droits de traduction, de reproduction et d'adaptation réservés pour tous les pays 


\title{
SUPERFLUOUS FALSTAFF: MORALITY AND STRUCTURE
}

\author{
Michael HATTAWAY
}

Falstaff est excessif : par sa taille, par son comportement et par sa profusion rhétorique. II est en quelque sorte une tumeur allégorique sur le corps politique, qui à d'autres endroits se forme à partir du discours des chroniques plutôt que de l'allégorie. II donne de la couleur à la pièce et, sur le plan rhétorique, donne de la couleur à la vérité, utilisant souvent la figure préférée de Machiavel, la paradiastole. Falstaff dépasse Henry IV, " fuyant » vers The Merry Wives of Windsor, Henry v (l'acteur Richard Moore décrivit jadis Pistol comme "Falstaff devenu baroque ") et, probablement, les deux parties de Sir John Oldcastle (1599). Ou bien nous pourrions invoquer la notion de supplément développée par Derrida, en ce que cette croissance secondaire devient partie intégrante de l'original : " banish plump Jack, and banish all the world ».

Falstaff is excessive: in size, behaviour, and in rhetorical copiousness. In some ways he is an allegorical tumour upon the body-politic, which is elsewhere formed from the discourse of chronicle rather than allegory. He colours the play and, rhetorically, colours the truth, often using the figure favoured by Machiavelli, paradiastole. Falstaff out-grows Henry IV, 'escaping' to The Merry Wives of Windsor, Henry v (the actor Richard Moore once described Pistol as 'Falstaff gone baroque') and, probably, the two parts of Sir John Oldcastle (1599). Or we might invoke Derrida's notion of the supplement, in that this secondary growth becomes integral to the original whole: 'banish plump Jack, and banish all the world'.

SHALLOW. ... I beseech you, good Sir John, let me have five hundred of my thousand.

FALSTAFF. Sir, I will be as good as my word. This that you heard was but a colour.

SHALLOW. A colour I fear that you will die in, Sir John.

FALSTAFF. Fear no colours. Go with me to dinner. - Come, Lieutenant Pistol, come, Bardolph. - I shall be sent for soon at night.

(2 Henry IV, v.v.77-83, emphases added $)^{1}$

$\mathrm{T}$

he word 'colour', variously inflected, occurs ten times in 1 and 2 Henry IV. A complex word, it has to do with badging (the escutcheon of a knight), with that which is fictive, and, because it designates figurative language, with the relation between rhetoric and reality. (In this passage it also, of course, puns on 'choler', a fit of anger, and 'collar', the hangman's halter.) 'Colours' here are the brave shows and excesses of rhetoric that wrap or re-fashion the bare ribs of

\footnotetext{
${ }^{1}$ Quotations are taken from volumes in the New Cambridge Shakespeare, especially from The First Part of King Henry IV, ed. Herbert Weil and Judith Weil, (Cambridge: Cambridge University Press, 1997) and The Second Part of King Henry IV, ed. Giorgio Melchiori, (Cambridge: Cambridge University Press, 1989). Quotations from other texts have been silently modernized.
} 
truth. These superfluities help us interpret, I submit, not only the linguistic bravado of Falstaff but also the morality, a morality based upon scepticism, of the two plays.

If we consider the two Henry IV plays and Henry $V$ as narrative continuations of the action of Richard II, Falstaff, Pistol, and their hangers-on are parasites, surplus to the action, and their fustian language is superfluous to the Tudor writing of England. The title-page of the 1598 Quarto of 1 Henry IV implies this by advertising 'the battle at Shrewsbury [...] with the humorous conceits of Sir John Falstaff. These 'apes of idleness' (2 Henry IV, IV.ii.251) wish to push riot out beyond the boundaries of carnival, suppress the Lenten stuff of Bullingbrook's court, and supplement their stage presence by their rewriting of England, filled as it is with their philosophising grotesque. They are 'swaggerers': a form of the word is found on another titlepage, that of the 1600 Quarto of 2 Henry IV - 'with the humours of Sir John Falstaff and swaggering Pistol' - and it is used fourteen times in thirty lines in 2 Henry IV, II.iv. When Shakespeare uses ploce, the figure of repetition, like this, it is a sign he wishes us to defamiliarise the word, turn it about, savour it. 'Swaggerer' indicates not just a kind of character but a kind of acting, presentational rather than representational, an insidious theatrical excess, a rhetorical energy centre that might overheat. ${ }^{2}$ (Ben Jonson registered this same fear in some of his texts.) So Falstaff along with the other too-fast growing braggart soldiers 'colour' not only the writing but also the narrative or, we might say, they embody Derrida's notion of the supplement in that this secondary growth becomes integral to the original whole. 'Banish plump Jack, and banish all the world' (1 Henry IV, II.iv.397-8) is Falstaff's challenge to the once and future Justice Overdo's of this world.

From a different critical standpoint we may conclude that Falstaff inhabits what we might, easily but in a mystificatory way, call an 'alternative world', a realm of being rather than becoming. We could refine this by observing that, as Professor Laroque has definitively pointed out, Falstaff operated within a distinctive kind of time, a

\footnotetext{
${ }^{2}$ For an intriguing study of Falstaff's role in the play see Grigori Kozintsev, "Tavern on the Volcano", Shakespeare: Time and Conscience, trans. Joyce Vining, (London: Dennis Dobson, 1966), 175-208.

${ }^{3}$ Jacques Derrida, Of Grammatology, trans. Gayatri Chakravorty Spivak, (Baltimore MD: Johns Hopkins University Press, 1976), 269-316.
} 
'mysterious space in which forces, now benevolent, now malevolent, interacted, the object either of impatient expectation or of anxiety on the part of individuals and groups alike'. ${ }^{4}$ However, throughout most of Part 2 we feel that Falstaff has fallen from mythic into historical time: Falstaff is no 'squire of the night's body' (1 Henry IV, I.ii.20) but is all too gross and material, a reality principle, an actor and doer on the stage of the world, a thief. He is also a touchstone for the ethics and efficacy of governance. (Ben Jonson would have branded him an 'enormity'.)

These two complementary readings are encapsulated in that wonderful uncopious string of monosyllabics: 'I shall be sent for soon at night' (in fact Falstaff's penultimate line in the play). At Stratford I once heard Hugh Griffiths take, to huge effect, what seemed to be a five second pause in its middle: 'I shall be sent for soon [pause] at night.' Falstaff stands both for a festive or Dionysian presence - Harry will, he hopes, soon crave his attendance once again - and also for the ineluctable nature of things - time's narrative reveals that night will inevitably follow day and that malevolent night-spirits might once again stalk the land. In the event, Falstaff, that erstwhile 'minion of the moon' (1 Henry IV, I.ii.21-2), does not come back, but others do. The reach of the Plantagenet state, like that of the Tudors and Stuarts, always exceeded its grasp.

That final exit notwithstanding, Falstaff did sustain a ghostly afterlife, and not only in The Merry Wives of Windsor. Seeming dead at Shrewsbury, he rose to play on through Part 2, and in Henry $v$ his role is filled by Pistol. The actor Richard Moore once described Pistol as 'Falstaff gone baroque': Pistol is without substance, he is the old knight rewritten in a language that consists largely of shreds and patches. He is like one who, in Marston's formula, makes 'commonplace books out of plays'. ${ }^{5}$ We might also remember how, in Sir John Oldcastle (1599), the hero, who bears Falstaff's unrevised name, has been transmuted from a 'pampered glutton' into a 'valiant

\footnotetext{
${ }^{4}$ François Laroque, Shakespeare's Festive World, trans. Janet Lloyd, (Cambridge: Cambridge University Press, 1991), 201-2.

5 John Marston, The Scourge of Villainy, (London, 1598), Sig. H4; ; Tiffany Stern alerted me to this figure.
} 
martyr'. ${ }^{6}$ In this text the character that, pace the Oxford editors, we remember as Shakespeare's 'Falstaff' is strangely rewritten as Sir John, the parson of Wrotham, who not only maintains an ingle named Doll, but also robs Hal, now Henry v, when the king finds himself alone on Blackheath. In this episode, however, it is in vain that the King summons his un-rewritten 'old thieves', Falstaff, Poins, and Peto (III.iv.60-4).

Remember too the ending of Bartholomew Fair in which Falstaff, that 'whoreson little tidy Bartholomew boar-pig' (2 Henry IV, II.iv.187-8) as Doll calls him, has another kind of afterlife. The enormities of the fair defeat the best endeavours of Justice Overdo, and he invites the rest of the characters (referred to as 'actors') to his house for supper.

'I shall be sent for soon at night': Falstaff's line, which concludes the most uncomfortable sequence of the play, is, as we have seen, embedded in word-play. Hal, as he intimated that he would, has banished Falstaff: 'I know thee not, old man' (2 Henry IV, v.v.43). Critics used to structure the play as a Psychomachia, a struggle for the soul of the Prince between virtue and vice, the Chief Justice and Falstaff that 'grey Iniquity' (1 Henry IV, II.iv.376). Hal, of course, finally embraces justice and virtue.

So what makes us uncomfortable as we watch the new king in action? Is it just his lack of remorse, the public betrayal and ritual 'baffling' or cruel humbling of his friend, at a moment when even Machiavelli might have encouraged us to expect clemency? Do we lament a Lenten suppression of wine and wassail, the excess of carnival?

Make less thy body hence, and more thy grace, Leave gormandizing, know the grave doth gape

For thee thrice wider than for other men. (2 Henry IV, v.v.48-50)

Do we rationalise Hal's behaviour, and regard the banishment as a pragmatic good - or at least one driven by raison d'état?

It seems to me that Francis Bacon must have been keeping company with Shakespeare - although he was certainly was not writing

\footnotetext{
${ }^{6}$ Michael Drayton and others, The True and Honourable History of the Life of Sir John Oldcastle, in C. F. Tucker Brooke, ed., The Shakespeare Apocrypha, (Oxford: Clarendon Press, 1908), Prologue, 129.
} 
his plays. So, when we watch a performance, do we invoke an Epicurean cynicism concerning what Bacon in The Colours of Good and Evil of 1596, the year before our play, called 'the Stoics' felicity placed in virtue'?

That is like the felicity of a player who, if he were left of his auditory and their applause, he would straight be out of heart and countenance; and therefore they [the Epicureans] call virtue bonum theatrale (emphasis added). ${ }^{7}$

If this is an act that is good only in so far as it is perceived, it is particularly vile. The first act of the new king is, to use a word of Richard II's, to 'monarchise'. In what should be the defining act of his first days in office Henry $\mathrm{v}$ reveals himself as a yet another 'harlotry player'.

Putting it another way, Hal, to use the somewhat theatrical terms of one of Bacon's most famous essays, is guilty of both dissimulation (not seeming to be what you are) and simulation or 'false profession' (pretending to be what you are not), a habit 'more culpable' in Bacon's eyes. ${ }^{8}$ The first great advantage of simulation and dissimulation is 'to lay asleep opposition and to surprise' 9 - the banishment looks back to reprehensible elements of the betrayal at Gaultree Forest (see below). Innocent Gentillet in his Contre Machiavel inveighed against Machiavelli for arguing for dissimulation

\footnotetext{
${ }^{7}$ Francis Bacon, Essays, ed. W. Aldis Wright, (London: Macmillan and Co., 1865), 249; compare "It's not worth, virtue, (that's bonum theatrale,) wisdom, valour, learning, honesty, religion, or any sufficiency for which we are respected, but money, greatness, office, honour, authority; honesty is accounted folly; knavery, policy; men admired out of opinion, not as they are, but as they seem to be: such shifting, lying, cogging, plotting, counterplotting, temporizing, nattering, cozening, dissembling, that of necessity one must highly offend God if he be conformable to the world, Cretizare cum Crete, or else live in contempt, disgrace and misery." (Robert Burton, The Anatomy of Melancholy, ed. Floyd Bell and Paul Jordan-Smith, (New York: Tudor Publishing Co., 1948), 53), and "Whatever [philosophers as opposed to Christians] did or suffered was either to purchase fame to themselves, or to merit reward by it; their aim and end was not God's glory, but their own honour and glory, and virtues are to be judged, not by their actions, but by their ends. Yea, they called virtue, bonum theatrale, as if a man would not be virtuous if he had not spectators to take notice of him: but it is false, for virtue will be as clear in solitudine as in theatre, though not so conspicuous; only it may grow more strong by the observation and applause of others, as an heat that is doubled by the reflection.' (Richard Younge, A Christian Library (London, 1660), 119) - Prof. Robin Headlam Wells alerted me to this last quotation.

8 Martin Dzelzainis, "Bacon, 'Of Simulation and Dissimulation”, A Companion to English Renaissance Literature and Culture, ed. Michael Hattaway, (Oxford: Blackwell, 2000), 233-40.

${ }^{9}$ Bacon, Essays, 21.
} 
in Chapter 18 of The Prince: 'faith, clemency, and liberality', he takes Machiavelli to assert, 'are virtues very damageable to a prince, but it is good that of them he have only some similitude and likeness.' ${ }^{10} \mathrm{Hal}$ goes further and 'simulates', pretending that he has turned away his former self, the wag of Eastcheap, and is now an upright king through whose mouth might come the laws of England. ${ }^{11}$ The great Russian film director Grigori Kozintsev felt that Hal's debauchery was a mask. ${ }^{12}$ I am not so certain.

The fat man gave me my cue for suspicion: 'That you heard was but a colour'. Is Falstaff cheering himself up? Hal does drop hints that the banishment might be conditional, which enables us to charge him with dissimulation. Hal had seemed to reform at the conclusion of Part 1, but is cheerfully back in Eastcheap at the opening of Part 2. Or is Falstaff redefining, in a way that is tempting but excessive, the climatic act of this double play, which is also the first act of a new king? Falstaff's construction of the king's action is that it is but a 'colour'. In the $O E D$ colour is defined in general terms as 'that which serves to conceal or cloak the truth, or to give a show of justice to what is in itself unjustifiable'. ${ }^{13}$ In particular, Falstaff's figure is an example of the figure of paradiastole, a figure that has recently seemed to be of great importance after being conjured back to life by Quentin Skinner. ${ }^{14}$ Paradiastole, the figure of redescription, turns out to be a key technique for disparaging virtue and excusing vice. The Epicureans redefined virtue, as we have just heard from Bacon, by the use of this figure.

\section{Here is Quintilian on paradiastole:}

To this figure [synoikeiosis] [the Greeks] oppose distinctio, which they

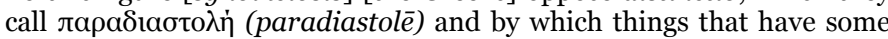
similitude are distinguished, as, 'When you call yourself wise instead of cunning, brave instead of presumptuous, frugal instead of miserly.' Such designations, however, depend wholly on definition, and therefore, I

\footnotetext{
${ }^{10}$ Innocent Gentillet, A Discourse upon the Means of Well Governing a Kingdom. against Nicholas Machiavell, trans. Simon Patericke, (London, 1602), 275.

${ }^{11}$ See 2 Henry VI, IV.vii. 5-6.

12 Kozintsev, 184.

13 OED, colour $\mathrm{n}^{1}, 11$.

14 Quentin Skinner, Reason and Rhetoric in the Philosophy of Hobbes, (Cambridge: Cambridge University Press, 1996), 161-72.
} 
doubt whether a sentence of that kind can properly be called figurative. ${ }^{15}$

I, on this occasion a nominalist, think it is a figure, since it is not about recategorisation, res pro re, but rather about rewriting, verbum pro verbo, for the purpose of 'colouring', for adjusting moral perspectives upon behaviour. ${ }^{16}$

Puttenham defined the figure thus:

Paradiastole [...] is, when by a mannerly interpretation, we do excuse our own vices, or other men's whom we defend, by calling them virtues. ${ }^{17}$

One expects 2 Henry $I V$ to end with some sort of moral certainty: instead the political resolution is cloaked in moral ambiguity. Along with the seasonal metaphors that Professor Laroque has highlighted in his passages on Falstaff, we might recognize paradiastole as Falstaff's keynote figure. Indeed, as we have seen, the very name 'Sir John Falstaff' is a re-writing of 'Sir John Oldcastle', the protestant martyr, whose name figured in a non-extant performance text of the play created about $1596 .{ }^{18}$

A proclivity to paradiastole is the charge that was laid against Machiavelli by Gentillet, ${ }^{19}$ and later commentators have recognized the technique in chapters 16-18 of The Prince, where Machiavelli examines generosity and parsimony, cruelty and compassion, love and fear (or integrity and cunning). ${ }^{20}$ What Gentillet wrote about Machiavelli's use of distinctiones applies perfectly to Falstaff's justification for playing dead after his brush with Douglas. Here is Falstaff:

\footnotetext{
15 Quintilian, Institutes of Oratory, 9.3.65.

16 On this see Skinner, 144 and 150.

${ }^{17}$ Henry Peacham, The Garden of Eloquence, (London, 1577) Sig. Niiiiv; George Puttenham, The Arte of English Poesie, (London, 1589), 154; cf. Richard Sherry, 'Paradiastole, when we so grant somewhat that we take away some thing that is near unto it' (A Treatise of the Figures of Grammar and Rhetoric, (London, 1555), f. 39" ; Angel Day, 'Paradiastole, when with a mild interpretation or speech, we colour others or our own faults, as when we call a subtle person, wise, a bold fellow, courageous, a prodigal man, liberal. (The English Secretary, (London, 1592), Sig. N3

18 Douglas A. Brooks, "Sir John Odlcastle and the Construction of Shakespeare's Authorship.” SEL 38 (1998): 333-61.

19 Skinner, 172.

20 'Machiavelli would expect his readers to recognize that chapters sixteen to eighteen of The Prince are a virtuoso exercise in paradiastole, the redescription of behaviour in order to transform its moral significance' (Niccolò Machiavelli, The Prince, ed. and trans. David Wootton, (Indianapolis: Hackett Pub. Co., 1995), xxxiv.
} 
'Sblood, 'twas time to counterfeit, or that hot termagant Scot had paid me, scot and lot too. Counterfeit? I lie, I am no counterfeit. To die is to be a counterfeit, for he is but the counterfeit of a man who hath not the life of a man. But to counterfeit dying when a man thereby liveth is to be no counterfeit, but the true and perfect image of life indeed. (1 Henry $\mathrm{V}$, V.iv.111-16)

And here is Gentillet, speaking of 'goodly distinctions well trussed together':

such subtleties and palliations [...] are but ridiculous things. For the affairs of the world ought to be governed by a common sense and solid judgment, and not by subtleties and distinctions which should be sent unto sophisters and logicians to maintain their arguments in schools. ${ }^{21}$

It has become a commonplace to call Falstaff a 'lord of misrule'. I want to show how he stands not just in opposition to the Chief Justice but also, within a pattern of sustained dialectic, to Bullingbrook himself and to Hotspur. Falstaff is a historical marker, a stain injected into the circulatory system of the body politic. As Edmond in Lear remarks, 'Men / Are as the time is' (King Lear, v.iii.31-2) and, as the Moscow Arts Theatre recognised, a king is defined not by his personality but by the behaviour of those about him. Like Falstaff, Bullingbrook is a master of dissimulation. This king seized the crown of England, and then demands Hotspur's prisoners so that their ransom might go into his exchequer. This is in the national interest: an expanding and centralising state, as Queen Elizabeth knew, demands funding.

In a kind of quotation of the episode, Falstaff, the king of shadows, rides to Gadshill to have his purse stuffed with crowns.

GADSHILL. ... There's money of the King's coming down the hill. 'Tis going to the King's exchequer.

FALSTAFF. You lie, ye rogue, 'tis going to the King's tavern.

$$
\text { (1 Henry IV, II.ii.42-3) }
$$

His retort is a perfect example of paradiastole, a reminder that Bullingbrook's regime change or coup d'état may well have set some things to right but was also a cause of social decomposition.

Falstaff himself, when he ascends the mock throne in the tavern and assumes the crown - actually a cushion - is another paradiastole,

${ }^{21}$ Gentillet, 269. 
a rewriting of Bullingbrook. The playlet is a significant social event or, to use a metaphor of Kozintsev's, 'a mine detector: old shells not yet deactivated are concealed in the flesh of every century, and, in thoughts concerning this [play], they reveal their presence.'22 'This chair shall be my state' (1 Henry IV, II.iv.312) puns on 'state': the chair is both a play throne and an index of Bullingbrook's lack of status; the crown, signified as a domestic object, is desacralised. Falstaff even redraws the royal icon:

... That thou art my son I have partly thy mother's word, partly my own opinion, but chiefly a villainous trick of thine eye, and a foolish hanging of thy nether lip, that doth warrant me. (II.iv.333-5)

And later he rewrites himself making a distinction between the true Falstaff and Falstaff the dissimulator:

If that man should be lewdly given, he deceiveth me, for, Harry, I see virtue in his looks. (II.iv.351-2)

Hal rewrites the text yet again:

Thou art violently carried away from grace. There is a devil haunts thee in the likeness of an old fat man; a tun of man is thy companion. Why dost thou converse with that trunk of humours, that bolting-hutch of beastliness, that swollen parcel of dropsies, that huge bombard of sack, that stuffed cloak-bag of guts, that roasted Manningtree ox with the pudding in his belly, that reverend Vice, that grey Iniquity, that father Ruffian, that Vanity in Years? Wherein is he good, but to taste sack and drink it? Wherein neat and cleanly, but to carve a capon and eat it? Wherein cunning, but in craft? Wherein crafty, but in villainy? Wherein villainous, but in all things? Wherein worthy, but in nothing? (II.iv.37080)

Rhetorical amplification, as every schoolboy knew, depended upon speaker's talents for 'invention', but Hal's copiousness consists not merely in repetition, in finding yet another way to project the same insult, but in a redescription of Falstaff. We remember Dr Johnson's great insight into Hal's first soliloquy, 'I know you all ...' (1 Henry IV, I.ii.155-77). The speech, Johnson, wrote, 'exhibits a natural picture of a great mind offering excuses to itself and palliating those follies which it can neither justify nor forsake.'23 (This is why I disagree with

\footnotetext{
22 Kozintsev, 217-18.

23 Samuel Johnson, Samuel Johnson on Shakespeare, ed. H. R. Woodhuysen, (Harmondsworth: Penguin Books, 1989), 198.
} 
Kozintsev.) As at the end of the play when Hal banishes the old man we are uncomfortable, and it is difficult not to reach for a modern notion like projection, a psychological defence mechanism: Hal is surely projecting a degree of hatred of Falstaff, his own shadow-self or second body, upon his friend.

After that flyting match of redefinitions in Eastcheap we need scarcely comment on Falstaff's demolition of the feudal valour of Hotspur: 'the better part of valour is discretion' (1 Henry IV, v.iv.11617) or on the earlier honour soliloquy where, in the Machiavellian context of not keeping faith, ${ }^{24}$ he redefines not only the virtue but the nature of words themselves: 'What is that "honour"? Air'. Therefore 'honour is a mere scutcheon': that is another kind of 'colour'. His self'catechism' (1 Henry IV, v.i.138) is a sophomoric set of rhetorical questions. As Gentillet wrote, 'For what man is so brutal or ignorant that seeth not with his eye how Machiavel delights to mock and play with the most excellent virtues among men?'25

Like jester, like king. Bullingbrook has a facility for redescription equal to that of Falstaff. We remember Hotspur on the King's refusal to ransom Mortimer:

Never did bare and rotten policy

Colour her working with such deadly wounds,

Nor never could the noble Mortimer

Receive so many, and all willingly.

Then let not him be slandered with revolt.

(1 Henry IV, I.iii.107-11, emphases added)

Not only has policy concealed itself in valour but also Mortimer's political actions have been redescribed as revolt. Bullingbrook is indeed the supreme Machiavellian. A mirror image of Falstaff, he will, as Worcester laments, define and redefine the actions of his enemies:

Look how we can, or sad or merrily,

Interpretation will misquote our looks,

And we shall feed like oxen at a stall,

The better cherished still the nearer death.

(1 Henry IV, V.ii.12-15, emphasis added)

\footnotetext{
24 Gentillet, 255 .

25 Gentillet, 275; for analogous tropes in Tacitus, see Skinner, 163.
} 
Bullingbrook even rewrites himself by having Sir Walter Blunt wear the escutcheon or colours of the King. And the morality of Gaultree is summed up as well by Gentillet as by anyone:

Neither is it to be feared that a prince cannot always find sufficient reasons to cover and colour that violation and breaking of his faith. Likewise it must be considered that all forced promises may be broken (especially when they concern the commonwealth) as soon as the force is passed. (emphasis added) ${ }^{26}$

What is notable is that Gentillet implicitly recognises that there may be a clash or contradiction between honour imperatives for individuals and states and that in this instance arresting the leaders of the insurrection may save the lives of common soldiers. ${ }^{27}$

In Part 2 Falstaff and Doll take part in the equivalent of Part 1's mock-king scene, a play within a play, here to the accompaniment of music. This is where Falstaff, left with Doll Tearsheet, is, for a few moments, at ease - and who else is at ease in this play? Doll had entered red-faced, caused presumably by rouge and drinking; as Mistress Quickly puts it, 'too much canaries [...] a marvellous searching wine, and it perfumes the blood ere we can say "What's this?" (2 Henry IV, II.iv.20):

Your pulsidge [pulse] beats as extraordinarily as heart would desire, and your colour, I warrant you, is as red as any rose, in good truth, la. (2 Henry IV, II.iv.18-20, emphasis added)

The normal polarities of dramatic irony in this scene are reversed (think of the triple overhearing scene in Love's Labour's Lost or the letter scene in Twelfth Night), in that we do not see the action from the point of view of those spying upon what they take to be a preposterous episode of 'Sir John in Love'.

This is, in fact, one of the greatest scenes of fervency in Shakespeare. Doll, 'coloured' as she is, loves this 'John', and Falstaff recognises who and what he is, an old man, lucky to have her, imagining death and fearing that, in bed with Doll, he might not be able to 'die' as once he did:

\footnotetext{
${ }^{26}$ Gentillet, 255; there are many further examples of the 'colouring' of truth and of faithbreaking in the pages that follow.

27 This point was made in discussion by Professor Peter Holland.
} 
DOLL. ... Thou whoreson little tidy Bartholomew boar-pig, when wilt thou leave fighting a-days and foining a-nights, and begin to patch up thine old body for heaven?

Enter the PRINCE and POINS, disguised [as drawers]

FALSTAFF. Peace, good Doll, do not speak like a death's-head, do not bid me remember mine end. ... Thou dost give me flattering busses.

DoLL. By my troth, I kiss thee with a most constant heart.

FALSTAFF. I am old, I am old.

DOLL. I love thee better than I love e'er a scurvy young boy of them all. (2 Henry IV, II.iv.187-91, 220-3)

This stichomythia depends upon each rewriting the other's line, and is all the more poignant because we know Falstaff might not ever get his end away again.

However, their on-stage audience, Hal and Poins, attempt to redescribe what we are watching:

PRINCE. Look whe'er the withered elder hath not his poll clawed like a parrot.

PoINS. Is it not strange that desire should so many years outlive performance? (2 Henry IV, II.iv.211-14)

As in the scene in Part 1, and later in the banishment scene, we feel that this badinage is a vehicle of hatred, born of self-loathing. Falstaff, reduced, exceeds the Prince, whose speech, to pluck a line out of Henry $V$, 'suits not in native colours with the truth':

Why, thou globe of sinful continents, what a life dost thou lead!

(2 Henry IV, II.iv.233)

Hal's bombast is simply ageist.

The ease of the two old lovers, however, occupies only a moment. Shakespeare is determined to eschew sentimentality, for Falstaff, when he spies the Prince, immediately repudiates or rewrites his lady, even though she is presumably sitting on his knee:

FALSTAFF. Thou whoreson mad compound of majesty, By this light [placing his hand on Doll] ${ }^{28}$ flesh and corrupt blood - thou art welcome.

DolL. How? You fat fool, I scorn you. ～～(2 Henry IV, II.iv.238-41)

${ }^{28}$ I have shifted the place of the stage direction which follows "blood" in most modern editions. 
Rowe's conjecture that 'flesh and corrupt blood' is an apostrophe to Doll, another paradiastole, is useful, although the words could be a muttered confession by Falstaff that emerges from self-loathing.

In conclusion: the supplemental excess of Falstaff, in both narrative and language, not only colours these plays but gives them a kaleidoscopic moral quality as we move around and through them. Endings are not conclusions, and our scepticism as readers and spectators must match Shakespeare's own. The texts explode the distinction between simulation and dissimulation: paradiastole makes all too problematic the essential self upon which Bacon's categories rely. Falstaff and the two Henries, father and son, are all given to rewriting, which reminds us to take their language as heuristic, interrogative - and certainly not simply expressive. 'Handy-dandy, which is the justice, which is the thief?' (King Lear, IV.v.146-7)

Michael HaTTAWAY University of Sheffield 